\title{
L'Assassinat du boulanger Denis François le 21
} octobre 1789

\section{Riho Hayakawa}

\section{(2) OpenEdition}

1 Journals

\section{Édition électronique}

URL : https://journals.openedition.org/ahrf/841

DOI : 10.4000/ahrf.841

ISSN : 1952-403X

Éditeur :

Armand Colin, Société des études robespierristes

Édition imprimée

Date de publication : 1 septembre 2003

Pagination : 1-19

ISSN : 0003-4436

Référence électronique

Riho Hayakawa, "L'Assassinat du boulanger Denis François le 21 octobre 1789 », Annales historiques de la Révolution française [En ligne], 333 | juillet-septembre 2003, mis en ligne le 20 avril 2004, consulté le 22 avril 2022. URL : http://journals.openedition.org/ahrf/841 ; DOI : https://doi.org/10.4000/ahrf. 841

Ce document a été généré automatiquement le 22 avril 2022.

Tous droits réservés 


\title{
L'Assassinat du boulanger Denis François le 21 octobre 1789
}

\author{
Riho Hayakawa
}

\section{RÉSUMÉS}

Un boulanger fut pendu et décapité par le peuple sur la place de Grève à Paris, le 21 octobre 1789. Aussitôt après, l'Assemblée nationale constituante institua la loi martiale. À première vue, cette action nous apparaît comme un lynchage cruel de la part d'émeutiers, mais il s'agissait d'une sanction sociale contre eux. Les députés de la Constituante décidèrent de traiter la violence du peuple par la force, c'est-à-dire la loi martiale. Le peuple et les députés suspectèrent un complot caché derrière cet assassinat du boulanger. Cependant il y eut entre les deux une divergence de vue sur ce « complot », quant à ses instigateurs.

The Assassination of Baker Denis François on 21 October 1789

A baker was hanged and decapitated by the people of Paris in the Place de Grève on 21 October 1989. Immediately thereafter, the National Constituent Assembly instituted "martial law". At first sight, this act appears as a callous lynching by the mob, yet it led to social sanctions against them. The deputies decided to meet popular violence with force, i. e. martial law. Both people and deputies suspected a plot behind the assassination of the baker. Yet views were divided as to the nature of the "plot" and its instigators. 